\title{
Assessment of Heavy Metals Pollution Status of the Pasture Grass around Katima Mulilo Municipal Solid Wastes Dumpsite, Namibia
}

\author{
J. Abah, P. Mashebe, and S. A. Onjefu
}

\begin{abstract}
Environmental effects of open wastes disposal continue to receive global attention. This study determined the heavy metals pollution status of pasture grass around Katima Mulilo municipal solid wastes dumpsite, Namibia. Samples of the pasture grass were collected from grassland around the wastes dumpsite and a control site and then analyzed for levels of the heavy metals: $\mathrm{Pb}, \mathrm{Cr}, \mathrm{Cd}, \mathrm{As}, \mathrm{Ni}, \mathrm{Co}, \mathrm{Cu}$ and $\mathrm{Mn}$ using standard analytical procedures. The results obtained revealed that $\mathrm{Mn}$ recorded the highest mean concentration of $102.50 \mathrm{mg} / \mathrm{kg}$ while Co recorded the lowest level $(0.13 \mathrm{mg} / \mathrm{kg})$. Generally, the present levels of the heavy metals were below their health regulatory limits. However, the degree of contamination of the pasture grass was significantly higher (paired sample mean $t$-test, $p<0.05$ ) in the samples collected around the wastes dumpsite with an index of 0.3502 . The loading values obtained from the principal component analysis of the heavy metals suggest that all the seven metals detected can be grouped under one main factor. Therefore, we recommend periodic monitoring of the levels of heavy metals in the pasture grass around the wastes dumpsite and advice precautionary measures in order to limit unintended exposures of livestock and hence, human beings to metals toxicities.
\end{abstract}

Index Terms-Cattle, pasture grass, heavy metal pollution, wastes dumpsite.

\section{INTRODUCTION}

Heavy metals contamination of the environment continues to generate public safety concern due to their various toxic effects. Forage plants under certain environmental conditions may absorb toxic metals from soil as well as from metal deposits on the surfaces of plant parts exposed to a polluted environment [1]. Plants are good environmental quality indicators and respond directly to air, soil and water quality [2], [3]. Since the plants can naturally draw the pollutants from their local environment, their chemical composition can indicate the degree of disturbances when assessed against background values obtained from unpolluted vegetation [4].

Heavy metals found in water, soil and fodder have significant impact on livestock particularly when the given metal is in the form that is bio-available [1]. Moreover, a

Manuscript received October 18, 2016; revised December 20, 2016. This work was supported in part by the University of Namibia under the Katima Mulilo Campus Five-year Research Agenda project \#3 of the theme: Agriculture and Environment.

J. Abah and P. Mashebe are with the Department of Mathematics, Science and Sport Education, Faculty of Education, University of Namibia, Katima Mulilo Campus, Private Bag, 1096, Katima Mulilo Namibia (e-mail: jabah@unam.na,pmashebe@unam.na).

S. A. Onjefu is with the Department of Natural and Applied Sciences, Namibia University of Science and Technology, Private Bag, 13388, Windhoek, Namibia (e-mail: sonjefu@nust.na). number of reports have confirmed the transference of trace metals from contaminated soil to plants and from plants to livestock [5], [6]. Among environmental pollutants, heavy metals affect biological functions and are potentially dangerous, particularly due to bio-accumulation along the food chain [7]. Human beings, as the final consumers in the food chain, are the likely recipients of high levels of minerals from contaminated food [6]. Since metals concentrations may consistently bio-magnify from one trophic level to the next, animals higher in the food chain may accumulate more toxins than their food contains [8]. Numerous studies have linked excessive accumulation of heavy metals to development of health abnormalities which include: cardiovascular, kidney, nervous and bone diseases, impairment of reproductive functions, spontaneous abortion, still birth, blue line on gum, mottling of teeth, low birth weight and abnormal pregnancy, gastrointestinal morbidity and language delay [9], [10]

Heavy metals are kept under environmental pollutant category due to their toxic effects in plants, humans, animals and food, with some of them such as of the heavy arsenic, cadmium, lead and mercury being identified as cumulative poison [11]. Heavy metals' ecosystem accumulation (water-soil-plant-animal) makes them very toxic and leads to undesirable consequences for live organisms [12], [13]. Grazing animals are directly affected by the consumption of forage and feed contaminated by airborne lead and somewhat indirectly by the up-take of lead or other metals through plant roots [14]. Increased concentrations of heavy metals in the body of domestic animals result in low fitness of animals and reproduction problems as well as in immunity decline and occurrence of cancerous and teratogenic diseases [15].

The increasing erratic rainfall occasioned by the prevailing climate change has greatly affected the availability of pasture grass in several communal areas of Namibia. This has compelled some cattle farmers to graze in open environment with palatable grass such as the grassland around Katima Mulilo municipal wastes dumpsite. Unfortunately, pasture grasses including other vegetations growing in such environment are prone to contamination by pollutants emanating from the wastes dumpsite. Importantly, the availability of safe pasture grass to animals such as cattle, is a necessity as it will not only guarantee the health and productivity of grazed animals but also reduce unintended human exposure to toxic substances via food chain contamination. However, the danger that fodders or animal products become potentially harmful for animal or human body results from their degree of contamination with different chemical pollutions [11].

Around the Katima Mulilo urban wastes dumpsites, 
atmospheric depositions of anthropogenic-derived particulates such as heavy metals may constitute an important source of pollutants load in environment. Due to trans-boundary effect, it is envisaged that heavy metal pollutants emitted from the Katima Mulilo urban dumpsite during incineration could be deposited in the surrounding grassland, pasture grass and other vegetations. The high utilization of the pasture grass for livestock grazing may expose the animals to certain levels of heavy metal pollutants via particulates inhalation, ingestion and dermal contact, and this has implication for transfer into human food chain. Appraisal of mineral status of grazing ruminants/livestock primarily involves sampling of forages fed to animals and soil used for growing these forage plants [16]. The forage plants under specific conditions may absorb toxic metals from soil as well as from metal deposits on the surfaces of plant parts exposed to a polluted environment [16]. Moreover, there is no research work done to establish the pollution status of the pasture grass around the wastes dumpsite. Therefore, this research is a baseline study with the main objective of determining the present levels of environmentally concerned heavy metals content of the pasture grass and compares the values with health regulatory guidelines limits for animal, especially cattle which form the most grazing livestock in the study area.

\section{MATERIALS AND METHODS}

\section{A. Study Area}

The study location is the pasture grass around Katima Mulilo municipal solid wastes dumpsite, located on latitude $17^{\circ} 50^{\prime} \mathrm{S}$ and longitude $24^{\circ} 25^{\prime} \mathrm{E}$ based on the Global Positioning System (GPS) geographical information recorded at the site on 28 May 2015. The pasture grass which provides rich grazing for livestock, especially cattle is located about $1.8 \mathrm{~km}$ east of the wastes dumpsite. The dumpsite has an estimated longest land dimension of $346.78 \mathrm{~m}$ and widest land dimension, 296.64m [17]. Solid wastes disposal at the site is based on open dumping and incineration and these practices have the potential to release toxic metal elements into the environment via trans-boundary pollution [17]. Thus, the pasture grass growing in the vicinity of the dumpsite could become contaminated by: 1). aerial deposition of heavy metal particulates emitted into the atmosphere during waste incineration. 2). absorption of heavy metals from soil solution, especially as the wastes dumpsite has been shown to significantly impacted on the metals content of the surrounding grassland soil [17]. Pasture grass contamination by heavy metals constitute health concern as they may become a vehicle for human food chain contamination with the heavy metals.

\section{B. Sample Collection and Pre-treatment}

Pasture grass samples were collected randomly from twelve points around Katima Mulilo municipal solid wastes dumpsite. The same species of the pasture grass were also randomly collected from a control site, a remote environment located $17 \mathrm{~km}$ west of the wastes dumpsite. Each location's samples were pooled together and washed properly with distilled water to remove adhering soil and other foreign particles in order to minimize contamination. Then, they were air-dried at room temperature in the laboratory for one week and further oven-dried at $60^{\circ} \mathrm{C}$ for two days until constant weight was obtained. Thereafter, the samples were ground into powder using stainless steel electric grinder. From the bulk powder, four subsamples were taken for each location and stored in air-tight high-density plastic container and they were analysed within two weeks.

\section{Sample Digestion and Analysis}

The method used for this digestion was the standard operation procedure of the Soil and Plant Analysis Laboratory, University of Wisconsin [18]. A measured $0.5 \mathrm{~g}$ each of the powdered pasture grass samples was taken into $50 \mathrm{ml}$ capacity Teflon digestion tube and $5 \mathrm{ml}$ of concentrated nitric acid was added. Then, the samples were soaked at room temperature for 3 hours after which the digestion tubes were covered with small glass funnels and placed on a block heater. The heater was set at $130^{\circ} \mathrm{C}$ and the mixtures were heated for 15 hours, removed and cooled to room temperature. Thereafter, $1 \mathrm{ml}$ of $30 \%$ hydrogen peroxide was added to each and the digestion tubes placed back on the block heater and heated for 30 minutes. Then, the digestion tubes were removed, cooled and another $1 \mathrm{ml}$ of $30 \%$ hydrogen peroxide was again added to each, placed back on the block heater and heated for another 30minutes. Then, the digestion tubes were removed and deionised water was added to each to the $50 \mathrm{ml}$ mark and left undisturbed for 30minutes before analyses for the levels of the heavy metals.

The digested samples were analyzed for the levels of lead, cadmium, chromium, arsenic, nickel, copper, cobalt, and manganese using ICP-OES (ICP: Perkin Elmer Optima 7000 DV) at the Analytical Laboratory Services, Windhoek Namibia.

\section{Data Analysis and Assessment of Pasture Grass Contamination}

The data obtained from quadruplet analyses of the samples were presented using the following descriptive statistics: mean, median, standard deviation, standard error, range, maximum, minimum, sum and counts. Then, the mean concentrations of the heavy metals were compared with their maximum tolerance limits for the most grazed animal (cattle) in the study area based on which informed decision about the feed quality was made. Principal component analysis was also performed on the data. Further contamination assessments were done using: 1 ). contamination factor $(\mathrm{Cf})$ in order to determine the individual contribution of the heavy metals to the feed quality. 2). degree of contamination $\left(C_{d}\right)$ in order to provide a measure of the degree of overall contamination of the pasture grass at a particular sampling site [19]. The assessment criteria were calculated using the following equations:

$$
\begin{gathered}
\mathrm{Cf}=\frac{\text { Sample metal concentration }}{\text { Meta l's maximum tolerance limit }} \\
\mathrm{C}_{\mathrm{d}}=\sum_{i=1}^{N} \mathrm{CF} i
\end{gathered}
$$

\section{RESULTS AND DISCUSSION}

\section{A. Concentrations of the heavy metals in the pasture grass}

Table I presents the descriptive statistics of lead $(\mathrm{Pb})$, 
chromium (Cr), Cadmium (Cd), arsenic (As), nickel (Ni), cobalt $(\mathrm{Co})$, copper $(\mathrm{Cu})$ and manganese $(\mathrm{Mn})$ determined in the pasture grass obtained around municipal solid wastes dumpsite and a control site. In the samples collected around the dumpsite, Mn recorded the highest mean concentration of $102.50 \mathrm{mg} / \mathrm{kg}$ while Co recorded the lowest level $(0.13$ $\mathrm{mg} / \mathrm{kg}$ ). The other results showed mean concentrations of $8.85 \mathrm{mg} / \mathrm{kg} \mathrm{Cr}, 7.10 \mathrm{mg} / \mathrm{kg} \mathrm{Cu}, 1.07 \mathrm{mg} / \mathrm{kg}$ Ni while $\mathrm{Pb}$ and As recorded $0.54 \mathrm{mg} / \mathrm{kg}$ and $0.37 \mathrm{mg} / \mathrm{kg}$ respectively. Cd was not detected in the samples. In the control samples, the results revealed similar pattern with $\mathrm{Mn}(17.56 \mathrm{mg} / \mathrm{kg})$ recording the highest level while $\mathrm{Co}$ and $\mathrm{Pb}$ recorded the lowest mean levels with the same value $(0.18 \mathrm{mg} / \mathrm{kg})$. The results of the other heavy metals were $5.46 \mathrm{mg} / \mathrm{kg} \mathrm{Cu}, 2.43 \mathrm{mg} / \mathrm{kg} \mathrm{Cr}, 0.67$ $\mathrm{mg} / \mathrm{kg} \mathrm{Ni}$ and $0.25 \mathrm{mg} / \mathrm{kg}$ As. Apart from $\mathrm{Cu}$, the results of the other heavy metals revealed higher mean levels in the pasture grass samples collected around the dumpsite (Fig. 1).

This result is not surprising as the wastes dumpsite is located just $1.8 \mathrm{~km}$ away from the pasture grass location. In an earlier study on the in-situ concentrations of heavy metals of the surface soil dusts at the wastes dumpsite in question, a significant enrichment of the surface soil with $\mathrm{Pb}, \mathrm{Cd}, \mathrm{Cr}, \mathrm{As}$, $\mathrm{Ni}, \mathrm{Co}, \mathrm{Mn}$ among other metal elements were reported [17]. Thus, the pasture grass under such close proximity may become comparatively contaminated with pollutants emitted during wastes incineration and decomposition at the dumpsite.

Generally, the present levels of the heavy metals recorded in the pasture grass samples obtained around both the dumpsite and control site were lower than the maximum tolerable limits of the heavy metals for cattle (Table II) [20], which are the main grazing animals in the area. Even though, the present levels of the heavy metals did not constitute acute health threat to the animals, there is concern for chronic effects due to the intensity of cattle grazing activities in the area. Prolong ingestion of the heavy metals contaminant- bearing pasture grass by cattle may lead to bio-accumulation of toxic metals into their body organs and this has adverse health implication for humans who consume beef and dairy milk products from these cattle. Heavy metals accumulate in tissues of dairy animals and are ultimately excreted in milk because of their non-biodegradable and persistent nature [21], [22], [23]. Milk as an excretion of the mammary gland can carry numerous xenobiotic substances, which constitute safety risk factor for dairy products and health of the consumer [24]. Metal residues in milk are of particular concern because milk is largely consumed by infants and children [25] who are very vulnerable to heavy metals toxicities. Consumption of milk from cattle reared in polluted sites leads to prolong exposure to environmental heavy metals, which results in considerable human health hazards [26]. For example, long-term exposure to lower levels of $\mathrm{Cd}$ and $\mathrm{Cr}$ leads to stomach irritation, kidney disease, lung damage and nervous manifestations [27]. A related study evaluated the contribution of anthropogenic pollution to toxic metal residues $(\mathrm{Cd}, \mathrm{Pb}$ and $\mathrm{As})$ in cattle in an industrialized area in Spain and found that $\mathrm{Cd}$ and $\mathrm{Pb}$ contents in the liver and kidney were moderately and significantly higher in calves from the industrialized area than in calves from the rural area [28]. In another study on toxic and essential metals in muscle, bone, liver and kidney of bovines grazed in a polluted area in Morocco, it was, found that the bovines were contaminated by toxic metals and that specific target organs for metals bioaccumulation showed higher heavy metals accumulation [29]. Thus, with notable toxic elements: $\mathrm{Pb}, \mathrm{Cr}$, As, Ni among the heavy metals detected in the pasture grass, it is likely that under prolonged and excessive bio-accumulation by the grazing cattle, the metals may adversely affect the quality, safety, and marketability of the meat and milk products from these animals.

TABLE I: DESCRIPTIVE STATISTICS OF THE HEAVY METALS IN THE PASTURE GRASS

\begin{tabular}{|c|c|c|c|c|c|c|c|c|}
\hline Sample Location & Parameter & $\mathbf{P b}$ & $\mathrm{Cr}$ & As & $\mathbf{N i}$ & $\mathrm{Cu}$ & Co & Mn \\
\hline \multirow{9}{*}{ 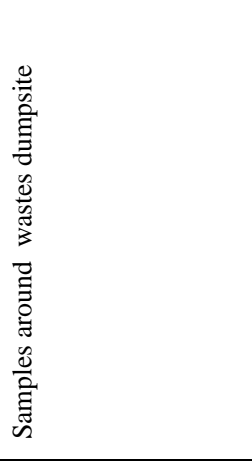 } & Mean & 0.52 & 8.92 & 0.36 & 1.10 & 7.08 & 0.12 & 102.07 \\
\hline & SE & 0.03 & 0.18 & 0.02 & 0.05 & 0.09 & 0.01 & 0.19 \\
\hline & Median & 0.52 & 9.04 & 0.36 & 1.11 & 7.07 & 0.12 & 102.16 \\
\hline & SD & 0.07 & 0.36 & 0.05 & 0.10 & 0.18 & 0.02 & 0.39 \\
\hline & Range & 0.16 & 0.80 & 0.11 & 0.22 & 0.42 & 0.05 & 0.85 \\
\hline & Minimum & 0.44 & 8.40 & 0.30 & 0.98 & 6.88 & 0.10 & 101.55 \\
\hline & Maximum & 0.60 & 9.20 & 0.41 & 1.20 & 7.30 & 0.15 & 102.40 \\
\hline & Sum & 2.07 & 35.68 & 1.42 & 4.40 & 28.31 & 0.49 & 408.27 \\
\hline & Count & 4 & 4 & 4 & 4 & 4 & 4 & 4 \\
\hline \multirow{9}{*}{ 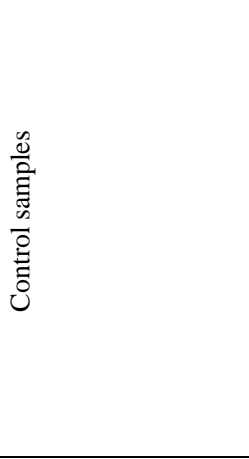 } & Mean & 0.18 & 2.40 & 0.23 & 0.66 & 5.43 & 0.18 & 17.41 \\
\hline & SE & 0.01 & 0.03 & 0.02 & 0.02 & 0.02 & 0.01 & 0.15 \\
\hline & Median & 0.18 & 2.40 & 0.22 & 0.67 & 5.42 & 0.17 & 17.37 \\
\hline & SD & 0.02 & 0.06 & 0.03 & 0.03 & 0.04 & 0.02 & 0.31 \\
\hline & Range & 0.05 & 0.14 & 0.07 & 0.08 & 0.09 & 0.04 & 0.69 \\
\hline & Minimum & 0.15 & 2.32 & 0.20 & 0.61 & 5.39 & 0.17 & 17.11 \\
\hline & Maximum & 0.20 & 2.46 & 0.27 & 0.69 & 5.48 & 0.21 & 17.80 \\
\hline & Sum & 0.70 & 9.58 & 0.90 & 2.63 & 21.71 & 0.73 & 69.64 \\
\hline & Count & 4 & 4 & 4 & 4 & 4 & 4 & 4 \\
\hline
\end{tabular}

Key: SD = Standard deviation; SE = Standard error 


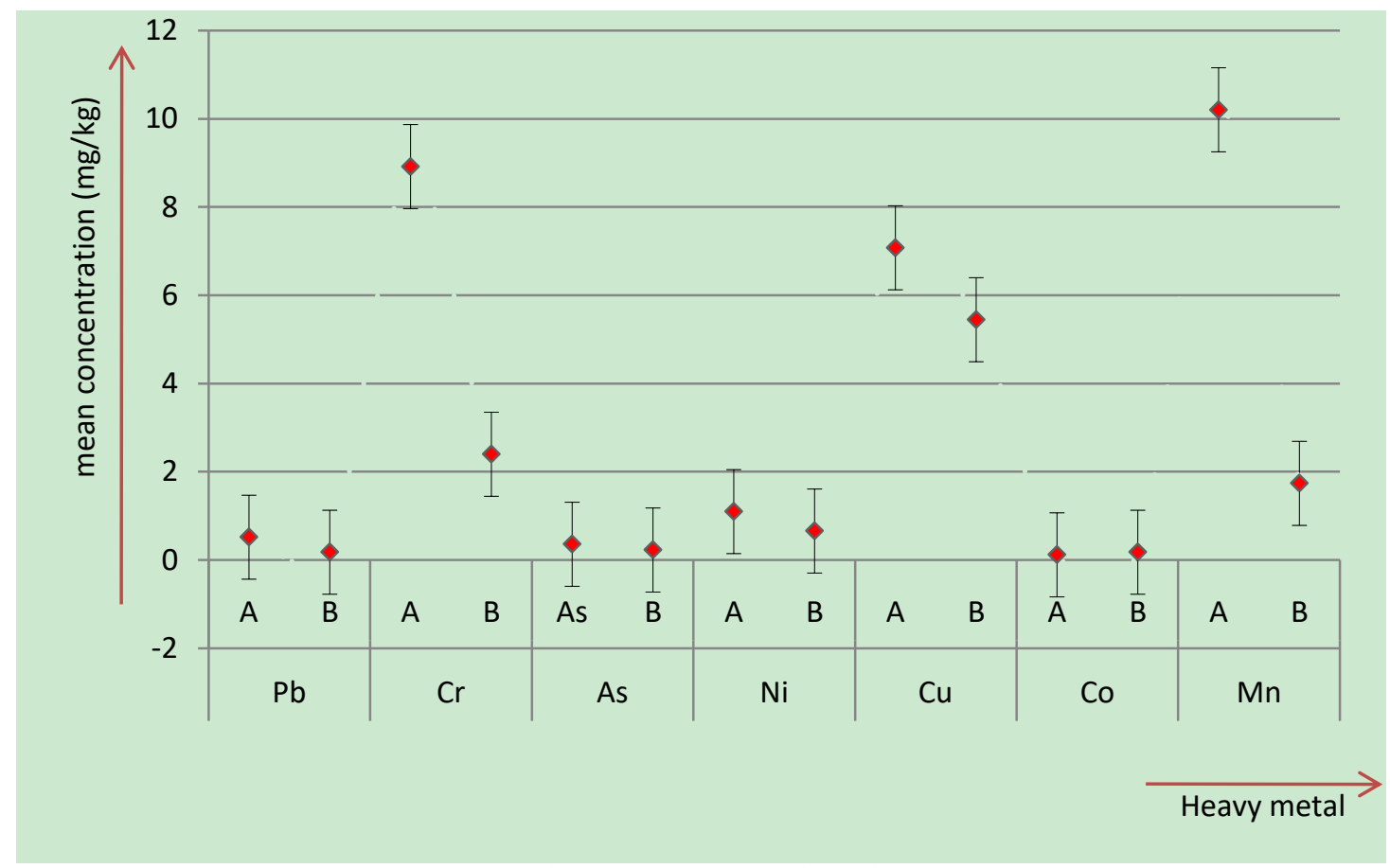

Key: $\mathrm{A}=$ grassland sample, $\mathrm{B}=\mathrm{Control}$ sample, $\mathrm{Mn}=\mathrm{x} 10$

Fig. 1. Relative mean concentrations of the heavy metals in the pasture grass.

\section{B. Contamination Assessment}

Fig. 2 shows the contamination indices of the heavy metals in the pasture grass samples. The trend of the result revealed that $\mathrm{Cu}>\mathrm{Cr}>\mathrm{Mn}>\mathrm{As}>\mathrm{Ni}>\mathrm{Pb}>\mathrm{Co}$. Based on the standard criteria for interpreting heavy metal contaminations of environmental components (Table II), the present results $(\mathrm{Cf}<1)$ show no contamination of the pasture grass. However, the degree of heavy metals contamination of the pasture grass from the sample locations (Fig. 3) showed that the samples around the dumpsite were more contaminated. The result of t-test analysis between the degree of metal contaminations of the pasture grass samples collected around the wastes dumpsite and control site was statistically significant $(\mathrm{p}<0.05)$. This may be due to the different degree of anthropogenic input of the heavy metals in the sample locations. This may due to the influence of the heavy metals particulates emitted from the wastes dumpsite during incineration and decomposition. Because of the close proximity of the pasture grass location to the wastes dumpsite, heavy metal particulates emitted into the atmosphere during wastes incineration at the dumpsites could easily be deposited unto the grassland via trans-boundary transfer effect. Solid wastes incineration in the open environment has the potential to release toxic metal elements into the environment [17]. Once present, heavy metals are persistent in the environment due to their non-degradable nature. This has implication for continued availability and absorption of the metal elements by the pasture grass which when ingested by grazing animals enter the human food chain and could constitute adverse health effects. The rising concern with human exposures to dietary heavy metals generally is due to the high potential of human beings to bio-accumulate metal elements into tissues which after prolong period could reach toxic levels [30]. This is mainly because heavy metals are non-biodegradable in nature which therefore, makes their presence in human foods even at very minute levels potential toxins [30]. In a similar view, it was indicated that heavy metals tend to accumulate in advanced organisms through bio- magnification effects in the food chain [31]. Thus, they can enter into human body, and accumulate in the human tissues to pose chronic toxicity [30]

\section{Principal Component Analysis of the Heavy Metals in the Pasture Grass Samples}

The loading values obtained from the principal component analysis (PCA) of the heavy metals concentrations in the pasture grass were as presented in Table III. Based on these values, the heavy metals can be grouped only under one factor. This is evident as Factor 1 accounts for $100 \%$ of the total variation in the data while Factor 2 accounts for $0.00 \%$. In the study area, it is envisaged that the main factor for the variations in the heavy metals content of the pasture grass samples may be related to the varying degree of anthropogenic inputs at each location. The results revealed that each element made a moderate contribution of -0.4000 to the variation in factor 1 . Thus, all the heavy metals can be grouped as follows: First factor: $\{\mathrm{Pb}, \mathrm{Cr}, \mathrm{As}, \mathrm{Ni}, \mathrm{Cu}, \mathrm{Co}$, $\mathrm{Mn}\}$.

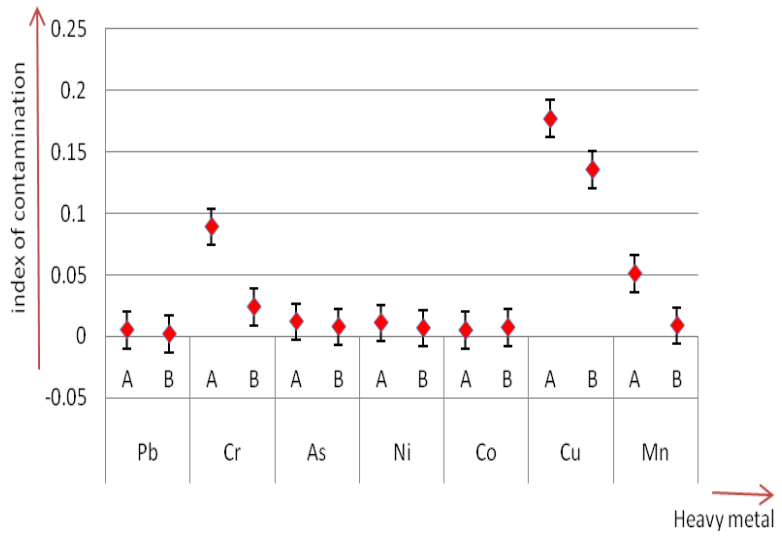

Key: $\mathrm{A}=$ grassland sample, $\mathrm{B}=$ Control sample

Fig. 2. Contamination factors of the heavy metals in the pasture grass. 


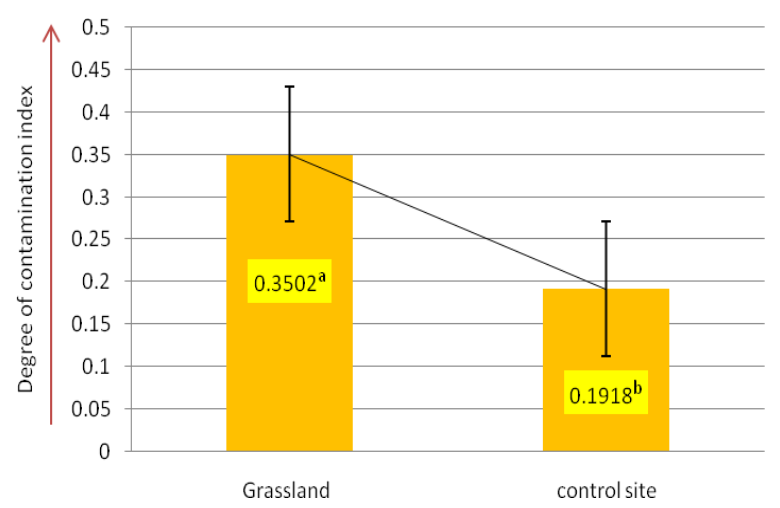

Fig. 3. Degree of contamination of the pasture grass per sample location, Different alphabete in the bars shows that the mean difference is statistically significant $(p<0.05)$.

TABLE II: STANDARD CRITERIA USED FOR ASSESSMENT OF THE HEAVY METAls Pollution OF THE PASTURE GRASS

\begin{tabular}{lll}
\hline $\begin{array}{l}\text { Heavy } \\
\text { metal }\end{array}$ & $\begin{array}{l}\text { MTL } \\
(\mathbf{m g} / \mathbf{k g})[\mathbf{2 0}]\end{array}$ & Cf assessment criteria $[\mathbf{2 3}]$ \\
\hline $\mathrm{Pb}$ & 100 & $\mathrm{Cf}<1, \mathrm{NC}$ \\
$\mathrm{Cd}$ & 10 & $1 \leq \mathrm{Cf} \leq 3, \mathrm{MD}$ \\
$\mathrm{Cr}$ & 100 & $3 \leq \mathrm{CF} \leq 6, \mathrm{CC}$ \\
$\mathrm{As}$ & 30 & $\mathrm{CF}>6, \mathrm{HC}$ \\
$\mathrm{Ni}$ & 100 & \\
$\mathrm{Cu}$ & 40 & \\
$\mathrm{Co}$ & 25 & \\
$\mathrm{Mn}$ & 2000 &
\end{tabular}

Key: MTL $=$ Maximum Tolerance Limit

$\mathrm{NC}=$ no contamination

$\mathrm{MD}=$ moderate contamination

$\mathrm{CC}=$ considerable contamination

$\mathrm{HC}=$ high contamination

TABLE III: PRINCIPAL COMPONENT ANALYSIS LOADING VALUES OF THE HeAVy MEALS IN THE PASTURE GRASS SAMPLES

\begin{tabular}{ccc}
\hline Heavy metal & Factor $\mathbf{1}$ & Factor $\mathbf{2}$ \\
\hline $\mathrm{Pb}$ & $\mathbf{- 0 . 4 0 0 0}$ & 0.2243 \\
$\mathrm{Cr}$ & $\mathbf{- 0 . 4 0 0 0}$ & -0.0572 \\
$\mathrm{As}$ & $\mathbf{- 0 . 4 0 0 0}$ & -0.1758 \\
$\mathrm{Ni}$ & $\mathbf{- 0 . 4 0 0 0}$ & -0.5319 \\
$\mathrm{Cu}$ & $\mathbf{- 0 . 4 0 0 0}$ & 0.7736 \\
$\mathrm{Co}$ & $\mathbf{- 0 . 4 0 0 0}$ & -0.1758 \\
$\mathrm{Mn}$ & $\mathbf{- 0 . 4 0 0 0}$ & -0.0572 \\
\hline \hline Eigenvalues & 7.0225 & 0.0000 \\
Percentage of variance & $100.00 \%$ & $0.00 \%$ \\
Cumulative percentage & $100.00 \%$ & $100.00 \%$ \\
\hline
\end{tabular}

\section{CONCLUSION}

The results of this study revealed varying concentrations of the heavy metals $(\mathrm{Pb}, \mathrm{Cr}, \mathrm{As}, \mathrm{Ni}, \mathrm{Co} . \mathrm{Cu}, \mathrm{Mn})$ in the pasture grass samples collected around the Katima Mulilo municipal solid wastes dumpsite and from control site. In all the samples, Mn recorded the highest mean concentration while Co recorded the least. The result of t-test: paired two samples mean analysis between the heavy metals concentrations in the pasture grass was statistically significant ( $\mathrm{p}<0.05$ ). However, the present levels of the heavy metals were lower than their maximum tolerable limits for cattle which constitute the main grazing animals in the study area. Results of the degree of contamination of the pasture grasses showed that samples collected around the wastes dumpsite were more contaminated. This may be due to the effect of trans-boundary pollution resulting from wastes incineration at the dumpsite located just $1.8 \mathrm{~km}$ from the sample area. Owing to the continued wastes disposal at the dumpsite, the surrounding pasture grasses will continue to receive pollutants via trans-boundary effect. This will affect the quality and safety of the pasture grasses which provide rich grazing for livestock, especially cattle in the study area and hence, portends high potential for the transfer of pollutants into the human food chain. Therefore, we recommend periodic monitoring of the heavy metals concentration in the pasture grasses and advice precautionary measures in order to limit unintended human exposures to metals toxicities.

\section{ACKNOWLEDGEMENTS}

The authors greatly acknowledged the financial support provided by the University of Namibia, Katima Mulilo Campus to undertake this study. We are also grateful to the Katima Mulilo Town Council for the approval granted us to collect the pasture grass samples around the municipal waste dumpsite. Finally, we are thankful to the technologists of Analytical Services Laboratory, Windhoek Namibia for the conducive analytical conditions provided for the laboratory preparations and analysis of the samples. God bless.

\section{REFERENCES}

[1] U. U. Udiba, D. B. Hassan, A. Mahmud, M. O. Odey, B. Gauje, S. M. Umar, I. Bashir, and A. M. Babakura, "Determination of contaminants levels in forage grasses," Archives of Applied Science Research, 2013, vol. 5 , no. 3, pp. 229-236.

[2] E. D'iaz and A. Massol-Deya, "Trace element composition in forage samples from a military target range, three agricultural areas, and one natural area in Puerto Rico," Caribbean Journal of Science, 2003, vol. 39 , no. 2, pp. 215-220.

[3] A. Kabata-Pendias, Trace Elements in Soils and Plants, CRC Press: New York, 2000, p. 432

[4] A. Massol-Deyá, D. Pérez, E. Pérez, M. Berrios, and E. Díaz, "Trace elements analysis in forage samples from a US Navy bombing range (Vieques, Puerto Rico)," Int. J. Environ. Res. Public Health, 2005, vl. 2 no. 2, pp. 263-266.

[5] Y. D. Ali, "Toxic elements in the food chain: exposure pathways to infants in selected areas of Limpopo province," M.Sc Thesis, University of South Africa, 2000.

[6] A. L. Oskarson, L. Jorham, J. Sindberg, N. Nilson, and L. Abanus, "Lead poisoning in cattle- Transfer of Lead to milk," Science of the Total Environment, 1992, vol. 111, pp. 83-94

[7] C. Makridis, S. Christos, R. Nikolaos, G. Nikolaos, R. Loukia, and L. Stefanos, "Transfer of heavy metal contaminants from animal feed to animal products," Journal of Agricultural Scienceand Technology, 2012, pp. 149-154.

[8] L.R. Monteiro, V. Costa, R. W. Furness, and R. S. Santos, "Mercury concentrations in prey fish indicate enhanced bioaccumulation in mesopelagic environments," Marine Ecol. Prog Ser., 1996, vol. 141, pp. 21-25.

[9] E. E. Ogabiela, E. M. Okonkwo, D. A. Oklo, U. U. Udiba, C. Hammuel, A. F. Ade-Ajayi, and A. Mahmud, "Status of trace metal levels of different age population of Dareta village, Anka, Nigeria," Journal of Applied Environmental and Biological Sciences, 2011, vol. 1, no. 6, pp 96-100.

[10] G. G. Yebpella, A. M. Magomya, U. U. Udiba, I. Gandu, S. M. Amana, V. C. Ugboaja, and N. L. Usman, "Assessment of Cd, Cu, Mn and Zn Levels in soil, water and vegetable grown in irrigated farm along river Kubani, Zaria, Nigeria," Journal of Applied Environmental and Biological Sciences, 2011, vol. 1, no. 5, pp. 84-89.

[11] T. Kocharea and B. Tamirb, "Assessment of dairy feeds for heavy metals," American Scientific Research Journal for Engineering, Technology, and Sciences, 2015, vol. 11, no. 1, pp. 20-31.

[12] I. Bogut, E. Has-Schön, R. Janson, Z. Antunović, and D. Bodakoš, "Concentrations of $\mathrm{Hg}, \mathrm{Pb}, \mathrm{Cd}$ and $\mathrm{As}$ in meat of fish-pond carp (Cyprinus carpio),” Agriculture, 2000, vol. 6, pp. 123-125. 
[13] L. Piskorová, Z. Vasilková, And I. Krupicer, "Heavy metal residues in tissues of wild boar (Sus scrofa) and red fox (Vulpes vulpes) in the Central Zemplin region of the Slovak Republic," Czech J. Anim. Sci. 2003, vol. 48, pp. 134- 138.

[14] D. Greene, "Effects of lead on the environment," 1993.

[15] J. Bires, J. Dianovsky, P. Bartko, and Z. Juhasova, "Effects on enzymes and the genetic apparatus of sheep after administration of samples from industrial emissions," Bio Metals, 1995, vol. 8, pp. 53-58.

[16] Z. I. Khan, K. Ahmad, N. Raza, F. Al-Qurainy, M. Ashraf, and A. Hussain, "Assessment of chromium concentrations in soil-plant-animal continuum: Possible risk for grazing cattle," Pak. $J$. Bot., 2010, vol. 42, no. 5, pp. 3409- 3414.

[17] J. Abah, P. Mashebe, S. A. Onjefu, and S. P. Malu, "Assessment of the in-situ concentrations of some heavy metals in surface soil dusts at the Katima Mulilo urban waste dumpsite, Namibia," International Journal of Advanced Scientific and Technical Research, 2015, vol. 4, no. 5, pp. 88-100.

[18] University of Wisconsin, "Standard operation procedure: Analysis of major, minor and trace elements in plant tissue samples with ICP-OES and ICP-MS," Soil \& Plant Analysis Laboratory, 2005.

[19] S. H. Rahman, D. Khanam, T. M. Adyel, M. S. Islam, M. A. Ahsan, and M. A. Akbor, "Assessment of heavy metal contamination of agricultural soil around Dhaka export processing zone (DEPZ), Bangladesh: implication of seasonal variation and indices," Appl. Sci. 2012, vol. 2, pp. 584-601

[20] National Research Council [NRC], "Mineral tolerances of animals," National Academic Press, Washington DC, USA, 2005.

[21] J. Burger and S. Elbin, "Metal levels in eggs of waterbirds in the New York Harbor (USA): Trophic relationships and possible risk to human consumers," J. Toxicol. Environ. Health A. 2015, vol. 78, pp. 78-91.

[22] M. A. Meli, D. Desideri, C. Roselli, C. Benedetti, and L. Feduzi, "Essential and toxic elements in honeys from a region of central Italy," J. Toxicol. Environ. Health A., 2015, vol. 78, pp. 617-627.

[23] L. Hakanson, "An ecological risk index for aquatic pollution control: A sedimentological approach," Water Res., 1980, vol. 14, pp. 975-1001.

[24] R. Pilarczyk, J. Wójcik, P. Czerniak, P. Sablik, B. Pilarczyk, and A. Tomza-Marciniak, "Concentration of toxic heavy metals and trace elements in raw milk of Simmental and Holstein-Friesian cows from organic farm," Environ. Monit. Assess., 2013, vol. 185, no. 10, pp. 8383, 2013.

[25] R. M. Tripathi, R. Raghunath, V. N. Sastry, and T. M. Krishnamoorthy, "Daily intake of heavy metals by infants through milk and milk products," Sci. Total Environ., 1999, vol. 277, no. 2, p. 299.
[26] I. Kar, S. K. Mukhopadhayay, A. K. Patra, and S. Pradhan, "Metal concentrations and histopathological changes in goats (Capra hircus) reared near an industrial area of West Bengal, India," Arch. Environ. Contam. Toxicol., 2015, vol. 69, pp. 32-43.

[27] M. Younus, T. Abbas, M. Zafar, S. Raza, A. Khan, A. H. Saleem, M. A. Idrees, Q. U. Nisa, R. Akhtar, and G. Saleem, "Assessment of heavy metal contamination in raw milk for human consumption," $S$. Afr. J. Anim. Sci., 2016, vol. 46, no. 2, pp. 16-169.

[28] M. Miranda, M. López-Alonso, C. Castillo, J. Hernández, and J. L. Benedito, "Effects of moderate pollution on toxic and trace metal levels in calves from a polluted area of northern Spain," Environment International, 2005, vol. 31, no. 4, pp. 543-548.

[29] A. Sedki, N. Lekouch, S. Gamon, and A. Pineau, "Toxic and essential trace metals in muscle, liver and kidney of bovines from a polluted area of Morocco," Sci. Total Environ., 2003, vol. 317, no. 1-3, pp. 201-205.

[30] J. Abah, P. Mashebe, and S. A. Onjefu, "Preliminary assessment of some heavy metals pollution status of lisikili river water in Zambezi region, Namibia," International Journal of Environment and Pollution Research, 2016, vol. 4, no. 2, pp. 13-30.

[31] M. N. Amirah, A. S. Afiza, W. I. W. Faizal, M. H. Nurliyana, and S Laili, "Human health risk assessment of metal contamination through consumption of fish," Journal of Environment Pollution and Human Health, 2013, vol. 1, no. 1, pp. 1-5.

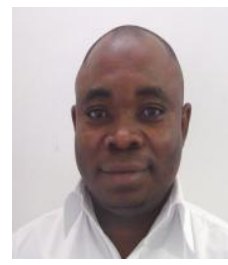

J. Abah was born in 1978. He obtained his bachelor of science (B.Sc hons) $\left(2^{\text {nd }}\right.$ class upper division) in 2002 from Benue State University, Makurdi, the master of science (M.Sc) analytical chemistry and the doctor of philosophy (PhD), analytical chemistry, both from the University of Maiduguri Nigeria in 2006 and 2010 respectively.

He worked as lecturer II at Yobe State Polytechnic Geidam and Fedederal Plytechnic, Nasarawa, Reserch officer I and Senior Research Scientist at National Cereals Research Institute, Badeggi, lecturer at Benue State University, Makurdi and presently a senior lecturer at the University of Namibia. As a seasoned researcher, he has published widely in international peer-reviewed journals. His research interest is in environmental pollution and remediation. 